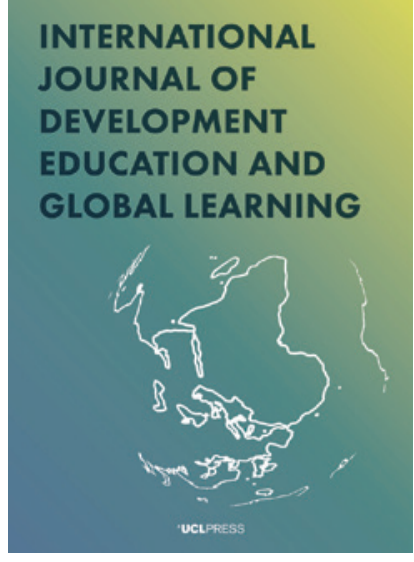

${ }^{\star}$ UCLPRESS

\title{
INTERNATIONAL JOURNAL OF DEVELOPMENT EDUCATION AND GLOBAL LEARNING
}

e-ISSN: $1756-5278$

Journal homepage:

https://www.uclpress.co.uk/pages/international-journalof-development-education-and-global-learning

\section{Teacher education for sustainable development within national frameworks: Squaring the circle from a German perspective}

\author{
Ellen Christoforatou ic
}

\section{How to cite this article}

Christoforatou, E. (2021) 'Teacher education for sustainable development within national frameworks: Squaring the circle from a German perspective'. International Journal of Development Education and Global Learning, 13 (1), 1-15. https://doi. org/10.14324/IJDEGL.13.1.01

Submission date: 28 April 2020

Acceptance date: 11 March 2021

Publication date: 30 June 2021

\section{Peer review}

This article has been peer-reviewed through the journal's standard double-blind peer review, where both the reviewers and authors are anonymized during review.

\section{Copyright}

(C) 2021 Christoforatou. This is an open-access article distributed under the terms of the Creative Commons Attribution Licence (CC BY) 4.0 https://creativecommons.org/ licenses/by/4.0/, which permits unrestricted use, distribution and reproduction in any medium, provided the original authors and source are credited.

\section{Open access}

The International Journal of Development Education and Global Learning is a peerreviewed open-access journal. 


\title{
Teacher education for sustainable development within national frameworks: Squaring the circle from a German perspective
}

\author{
Ellen Christoforatou* - University of Kassel, Germany
}

\begin{abstract}
This article deals with the question of how teacher education and teacher training in Germany - of which many aspects have been fragmentized - can nevertheless provide teachers with an adequate opportunity to systematically develop their professional competences in the field of education for sustainable development (ESD). Based on current education policy goals and relevant empirical research, the article offers a theory intended to cause coherence between three phases of teacher education and training in Germany, thereby integrating academic theory and ESD practice more consistently. Particular attention is given to teacher educators, educational managers, researchers and decision makers, who often have not acquired solid expertise in the specific area of ESD themselves. Their active inclusion is the key success factor in the intrinsic processes regarding organizational development at teacher education institutions.
\end{abstract}

Keywords: teacher education and training, education for sustainable development, change management, educational policy, conceptual approach, transformative learning

\section{Introduction}

'You do your homework and we'll do ours!' is a slogan of the German Fridays for Future movement. With this slogan, the movement is drawing attention to the shortcomings of climate policy, accusing responsible decision makers of ignorance and failure, and calling on the entire country to take immediate and responsible action. Interestingly, school students have received broad support from the older generation during their weekly school strikes. For example, in addition to the Parents for Future and the Scientists for Future movements, the Teachers for Future movement was formed in 2019, despite some legal concerns about whether teachers should be allowed to support their students during the school strikes.

The adults' behaviour towards the young people seems symptomatic of their despair in the face of the contradictions of their own actions in dealing with (non-) sustainable development. It also documents the determination of numerous teachers to provide the best possible support for the next generation in the context of formal education in order to help them take up new options in shaping their future. They want to offer their students sufficient opportunities to create their own innovative solutions to relevant problems of our time. Despite all the euphoria, however, it must be noted that although the concept of education for sustainable development (ESD) has been discussed in the academic community for some two decades, German teachers have not yet been fully prepared for the enormous challenges that this entails, whether during their initial teacher education or in their in-service training. 
Time and time again, it has been shown that the theoretical discourse on the development of competences in the area of ESD is not only hindered by misconceptions and misunderstandings within the field of ESD (Shephard et al., 2018); it also does not correspond to actual school practice. The United Nations Economic Commission for Europe (UNECE, 2011) Expert Group on Competences for ESD identified various competences that are considered particularly important for the implementation of ESD. In addition to the so-called sustainability competences, these are active professional competences of teachers, in particular: relevant cognitive skills, such as knowledge of the concept of sustainable development; basic knowledge of ecological systems; an understanding of global processes and of socially discussed approaches to problem solving; knowledge of the concept for Gestaltungskompetenz, that is, the ability to apply knowledge of sustainable development and to recognize problems of non-sustainable development (de Haan, 2008); the ability to change perspectives and a range of methods specific to ESD, but also special personal and social skills, such as communication and cooperation; the ability to empathize, willingness to innovate, and a tolerance of ambiguity and frustration (Hellberg-Rode and Schrüfer, 2016; Beule and Seybold, 2015). However, the majority of teachers do not succeed in implementing these in the classroom as they have simply not been trained to do so. Accordingly, in a quantitative study conducted as part of the Third Monitoring Report on the Mainstreaming of ESD in Germany, 69 per cent of all teachers stated that they had 'never' come into contact with ESD during their teacher education studies, and only 9 per cent of active teachers had attended ESD-specific in-service training within the past five years (Brock and Grund, 2019: 3). This shortcoming is all the more serious as teachers are intended to play a key role in the implementation of the Sustainable Development Goals (SDGs) (UNESCO, 2014).

Nevertheless, the German Action Plan adopted in 2017 is the first nationwide action plan whose goal is to structurally anchor ESD in the German education system (National Platform on ESD, 2017). With regard to the implementation of this action plan, for which slightly less than EUR14 billion has been earmarked nationwide until 2030, the Gewerkschaft Erziehung und Wissenschaft, the German union for those working in education and science, has stated that with regard to teacher education and training, there is 'a lot of good will but little visible progress' (Glaser, 2019: 12, my translation). While appreciating the numerous activities within the various teacher education institutions, and the efforts of individual stakeholders, it must therefore be noted that there is currently no jointly supported approach in Germany to structurally implement ESD in teacher education and training.

Seen in this light, the systematic, nationwide integration of ESD in the numerous teacher training and continuing education institutions in Germany is one kind of if not the - core 'homework' that needs to be done. To help achieve this end, this article analyses the special conditions that have so far prevented the systematic and consistent implementation of teacher education for sustainable development (TESD) in Germany. Against this background, a theory for the implementation of ESD in teacher education is presented, using various existing examples of good practice. Finally, the article discusses how existing impediments can be overcome by means of suitable organizational development processes, so that ESD can have a lasting effect on the breadth of German teacher education in the future.

\section{Teacher education in Germany: A patchwork quilt}

At first glance, it all seems so simple. With the new edition of the Orientation Framework for the Learning Area of Global Development in the Context of Education 
for Sustainable Development, which was first written in 2007, the Standing Conference of the State Ministers of Education and Cultural Affairs in the Federal Republic of Germany (Kultusministerkonferenz, KMK), in cooperation with the German Ministry for Economic Cooperation and Development (Bundesministerium für wirtschaftliche Zusammenarbeit und Entwicklung, BMZ), has developed a tool that is consistently oriented towards the model of sustainable development and explicitly incorporates the post-2015 agenda (KMK and BMZ, 2017). The aim of this expanded and updated document, which is no less than 450 pages in length, is to provide schools, teacher education institutions, administrators and curriculum developers in the individual states with guidance on how to implement the National Agenda. The explanations refer to the implementation of ESD in almost all teaching subjects, and also explicitly address requirements for teacher education. In addition to linking the core competences for ESD with specific subject-related competences, the framework contains exemplary learning units, which include material as well as teaching methods. Thereby it vividly depicts numerous possibilities for how students can develop their own competences, for example, in the areas of recognizing, assessing and acting. However, anyone who, given the prominence of the editors, draws hasty conclusions on the effectiveness of the tool is mistaken. Germany is dominated by a 'federalized', that is, decentralized, system of education where education is administered by the states. This means that the KMK, which was founded in 1948 as a voluntary association of state ministers of education and cultural affairs, is nothing more than an attempt at self-coordination in 'matters of educational policy, higher education, research policy and cultural policy of national importance with the aim of forming common opinions and decision making and representing common concerns' (KMK, 2014: n.p., my translation). With regard to the structured introduction of cross-sectional issues into educational processes, the KMK is proving to be a paper tiger. Despite all the appreciation of the achievements, successes and insights that have been, and are being, generated by the many ambitious implementation projects of the orientation framework, these are ultimately selective activities that are being carried out with the commitment and blood, sweat and tears of individuals, but which are usually not able to exert a long-term effect on the structures of the participating institutions, let alone on the individual states in Germany.

TESD can be interpreted as a 'multiple-level task/problem' (Bormann and Nikel, 2017: 802) involving numerous interdependent actors who exist and work independently from each other. No central or national German educational policy exists, which is why the status quo of TESD within the individual states already differs greatly, if only in terms of structural requirements and goals. What is more, a look at the information compiled by the German Commission for UNESCO on the status of implementation of the Global Action Programme on ESD reinforces the suspicion that not all German states have an interest in establishing structures that go beyond individual activities (Deutsche UNESCO-Kommission, 2020). Rather, it sometimes seems as if the term 'ESD' is used to consolidate and label temporary projects that have no intrinsic connection with each other. In any case, the statement by the KMK (2017: 5, my translation) that 'it is not yet possible to talk about a comprehensive and systematic anchoring of education for sustainable development in teacher education in the individual states' is still valid today.

Nevertheless, there are also examples of good practice in Germany. The state of Baden-Württemberg has integrated the guiding perspective of ESD into the new education plans for general schools in an exemplary fashion, and anchored it consistently and systematically in the state's curriculum guidelines. Furthermore, in 2015/16 the acquisition of interdisciplinary competences in the field of ESD was 
also laid down in the teacher-training curriculum for all future teachers in BadenWürttemberg in such a way that the topic is now anchored both in the educational sciences and in all subjects (Deutsche UNESCO-Kommission, 2020; see, for example, Staatliches Seminar für Didaktik und Lehrerbildung Freiburg, 2018). In contrast, the measures for implementing the World Action Programme in the neighbouring state of Hessen remain comparatively non-binding. There is still no requirement in Hessen's state legislation for ESD, which is why the activities concentrate on networking with those already involved on a voluntary basis. As well as the establishment of a school network Nachhaltigkeit lernen in Hessen (Learning Sustainability in Hessen), so-called Regionale Netzwerke BNE (Regional ESD Networks) have been formed which bring together ESD actors from the fields of formal and informal education, representatives of local authorities and the business community (Deutsche UNESCO-Kommission, 2020). In addition, a Runder Tisch BNE (Round Table on ESD) has been established involving institutions, organizations and actors essential for Hessen, although teacher education institutions are invited to participate only on a very selective basis.

The fact that the competences and responsibilities concerning TESD remain diffuse at state level is connected partly to the multi-phase nature of teacher education and training in Germany (Terhart, 2004). The first, university-based phase of teacher education, which ends with a first degree, is followed immediately by a second phase, which takes the form of a practical training period at a teacher training institute. In this phase, which lasts between 18 and 24 months depending on the individual state, the so-called trainee teachers already teach at a school for a (reduced) number of hours. Yet, their place of work is the teacher training institute, where they take part in courses by their assigned instructors, who also visit, advise and evaluate their lessons. Only after this second phase is the training considered to be completed. In-service training is offered to fully trained teachers - although most of the offers do not meet the academically proven criteria for the effectiveness of training courses (Lipowsky and Rzejak, 2019). In addition, participation in further training courses is rarely obligatory, offers are only taken up sporadically, and the choice of topics is made by the teachers themselves or agreed with the principal. Teachers who wish to undergo further training in the field of ESD therefore choose from a pool of further training courses offered by various providers (usually lasting between 90 minutes and two days), with the courses selected rarely being related to each other, let alone building on each other.

Any attempt to establish a model of TESD across all phases that can be connected in each case is further complicated by the fact that different ministries may be involved, depending on the individual state. In Hessen, for example, university education is the responsibility of the State Ministry of Higher Education, Research and the Arts, while the Hessian Lehrkräfteakademie (Teachers' Academy), an educational authority of Hessen's Ministry of Education and Cultural Affairs, is responsible for both practical teacher training and in-service training. The above-mentioned interdepartmental Runder Tisch BNE, which is dedicated to the implementation of the National Action Plan for ESD at state level, is in turn the responsibility of the Hessian Ministry of the Environment. A conditio sine qua non for the development and implementation of a corresponding concept would therefore be the political will of three ministers who-as in this case - represent different parties in the governing coalition.

In any case, any attempt at top-down regulation would be doomed to failure, if only because the universities in a given state offering teacher education would simply reject such a blatant encroachment on their autonomy (Holst and von Seggern, 2020). Certainly, the term ESD is now being increasingly used in the teacher education curricula at universities, and individual universities are already offering student 
teachers opportunities to deal with sustainable development issues during their studies. Examples include the Bildung - Transformation - Nachhaltigkeit (Education Transformation - Sustainability) certificate from the University of Koblenz-Landau; the Nachhaltigkeit und Bildung (Sustainability and Education) certificate from the University of Hildesheim; and the InterESD (Internationalization and Education for Sustainable Development) study profile from the University of Kassel. Nevertheless, ESD is still treated as an add-on to regular teacher education even at such institutions, and it is neglected, if not ignored, by numerous tertiary-level teaching staff (Brock, 2018; Christoforatou, 2017).

The problem areas, which have only been touched upon here, point up several dilemmas. On the one hand, ESD is a current and important cross-sectional task which should be included in all areas of teacher education and training. In addition to the successive phases described above, this also includes the subject-related, teachingrelated, academic and practical aspects of fragmented teacher education. On the other hand, the subject-related and interdisciplinary content to be taught often goes far beyond the subjects studied or taught by (prospective) teachers, and is therefore not the responsibility of individual subject areas, initial teacher education or in-service training courses. In addition, developing ESD-related competences is far from being part of the professional understanding of teacher-educators and trainers. Accordingly, the majority of them have neither sufficient knowledge of the concept of sustainable development, nor the necessary skills to cope with the associated requirements in teaching methods. It is (still!) not uncommon for the concept of sustainable development to be narrowed down to the solution of nature conservation and environmental issues, where social, political, economic, cultural and legal aspects are ignored. This misconception is one of the reasons why many educators find it difficult to find links to curricula or their own teaching and research priorities.

One thing is certain. As long as relevant activities in the field of ESD are supported by the commitment, expertise and personal network of individual teacher-educators, primarily from the natural and social sciences, broad segments of teacher education will be left out. However, there is reason for hope. Recently, change processes were initiated by the German Action Plan. Its overarching goal is to systematically embed the concept of sustainable development in all areas of education in Germany. Localities, regions, educational institutions and civil society actors in the field of informal education who are committed to the structural embedding of ESD currently have a range of funding opportunities available to them, for example through calls for proposals by the Deutsche Bundesstiftung Umwelt (German Environmental Foundation) or the Engagement Global (Service for Development Initiatives acting on behalf of the German Ministry for Economic Cooperation and Development). In order to ensure that such projects have an impact beyond the group of already committed actors, the funding criteria have been designed in such a way that in addition to contentrelated specifications, interdisciplinary cooperation between several stakeholders from different institutions plays a particularly important role in assessment. This means that more and more people whose understanding of the necessity and requirements of ESD is still underdeveloped (or non-existent) are (or must be) included in the design of projects. In consequence, there is a high risk of diluting the objectives. However, it is precisely such cooperation that offers the chance of getting on board stakeholders and decision makers who have not (yet) been convinced, and of using them constructively as sparring partners. In this way, the concept of sustainable development can be brought gradually into the spectrum of the educational landscape and become effective through joint action. 
But how might multi-phase TESD be designed conceptually and integrated systematically, especially in light of the fragmentation and diversity of interests? What criteria must be observed in this connection, and how can synergy effects be evoked between the different phases of teacher education? The following section is devoted to these questions. A theoretical approach is presented, along with recommendations for the elaboration of measures that consider the various prerequisites and needs.

\section{Teacher education for sustainable development: Conceptual approach}

The conceptual approach presented here aims to promote empowerment in the field of ESD: empowerment of students, teachers, teacher educators and other multipliers. The core question is how this group of people can be enabled to: (1) provide others with a realistic picture of the complexity of our world in a gentle and age-appropriate manner, and to show them how living beings, as differently as they organize their existences and as distantly as they may exist from each other, influence each other in their ways of life and living conditions; and, at the same time, (2) encourage and enable them to play a constructive and creative role in the forthcoming processes of social and economic change. With regard to this core question, it is important to acknowledge that, most often, educators have not had the opportunity to deal with those issues themselves yet: they are learners, too. Therefore, it is crucial to regard teachers (both future and in-service) as individuals who need to acquire heuristic knowledge, competences and capabilities that enable them to shape the future actively, on their own and with others.

Seen from this perspective, the demands to decolonize (teacher) education (Pirbhai-Illich and Martin, 2019) can also be applied to German teachers and teacher educators. They are increasingly required to moderate learning processes whose course of events they often cannot foresee, and in which they themselves are comparatively strongly involved as learners. Thus, dealing with issues of sustainable development in teaching/learning processes requires the ability to create transformative material and methods, as well as to establish new learning cultures that take into account the freedom and responsibility of the individual, and hence the open process. After all, teaching ESD is not about letting students choose the best option from existing or possible alternatives, but rather about encouraging them to invent the unimaginable. The corresponding shift in the self-image and role of teachers can hardly be overestimated.

In this respect, TESD is closely linked to Vanessa Andreotti's (2006) concept of critical global citizenship education. A consistent application of these principles to ESD is considered necessary because both Western ideas of progress, and values and moral concepts, will otherwise be projected unthinkingly on to the SDGs and their implementation. This makes it all the more important to be continually aware that the meaning and interpretation of individual SDGs sometimes differ enormously from one region of the world to another. It is therefore essential to integrate international cooperation partners, including those from the Global South, into the development and implementation of relevant projects in the field of ESD. In the process, the various stakeholders involved can experience at first hand that their 'location in the colonial matrix of power shapes the way [they] look at the world' (Mignolo, 2012: 293). On this basis, they are able to deconstruct individual and social narratives, thereby uncovering postcolonial power relationships, critically question their own (Western) educational concepts, and put to use the insights gained for the development of educational opportunities. Understood in this way, an internationalization of teacher education is 
indispensable in order to comprehensively prepare teachers and teacher-educators in the spirit of ESD (Quezada, 2012; Christoforatou, 2015). Teachers must be regularly provided with international learning opportunities and fields of experience. Crossnational teaching/learning scenarios are particularly useful for initiating changes in perspective (Barth and Rieckmann, 2009; Christoforatou, 2014; Christoforatou and Glaser, 2020). These offer teachers genuine occasions not just for developing their intercultural competences and for applying and expanding their foreign language skills; in order to analyse foreign teaching cultures and learning traditions, they are also able to critically question the often implicit concepts of 'good teaching' that prevail in Germany, as elsewhere. This way, teachers, teacher-educators and even educational managers may realize that the German educational system is not (yet) a system that prepares people to face the complexity, the uncertainty or the plurality of the world an insight that is essential, especially with regard to processes of school and classroom development, as well as governance processes, in the context of ESD (Burow and Gallenkamp, 2017).

The preceding remarks show that the integration of ESD in teacher education processes requires constructive participation by, and communication at eye level with, as many people involved in teacher education as possible. At the same time, very often the mere thought of participating in a structural implementation of this cross-sectional issue triggers feelings of resistance and of being overtaxed. It is not uncommon for academic ESD experts, teacher-trainers, school teachers and educational administrators to accuse each other of a lack of interest in theoretical background and research findings, ignorance of the (im)possibilities of teaching practice and a lack of visionary power. When tackling this issue, the idea of the so-called third space might serve as a useful approach. The third space is regarded as hybrid space (Bhabha, 1990) in which both authority disparities and the apparent dichotomy of academic knowledge and professional experience are eliminated (Zeichner, 2010). In this sense, the third space is a place of productivity, dynamism and personal development (Christoforatou, 2011) which offers opportunities to get to grips with global issues of sustainable development in authentic settings. For example, the framework for this might be provided by topicrelated cooperation with civil society actors from the Global South. By lending a hand there themselves, academics, educators, students and educational managers put themselves in other people's shoes and bring about changes of perspective. They experience different needs, concerns and potentials at first hand, and in the process begin to critically question their own ideas of ESD and their understanding of their role, thereby creating a common identity which will be regenerated again and again through continuous dialogue, both between international partners and on a local level. Last, the third space might even help the representatives of the three phases of teacher education, who are still rooted in very different organizational systems and culture, overcome their biases.

\section{Strategies for implementation}

Following on from the above, with regard to TESD, Germany is confronted with a particular challenge. Stakeholders need to create transparency and continuity between the different phases of teacher education. In order to establish structures in which TESD can grow and flourish successfully, it is therefore essential that the institutions involved jointly put together a suitable package of measures. Clearly, such a package of measures cannot look the same everywhere. Instead, it makes sense for the individual measures taken to differ depending on the region, educational policy requirements, 
general conditions at the institutions involved and the attitudes of the people involved after all, TESD is not least a negotiation process. To ensure that this negotiation process is not only effective, but also leads to decisions and agreements that can be implemented and actually have a lasting impact on the breadth of teacher education, with regard to the elaboration of measures, the following recommendations are made.

\section{Diagnose and take into account the educational realities of the cooperating institutions - right from the start}

The success of long-term projects in the field of TESD that have an impact on structures therefore depends largely on how intensively and self-critically the participating teacher education institutions and cooperation partners take stock of their initial conditions and openly communicate with each other - however difficult, time-consuming and sometimes devastating this process may be. After all, trust forms the major base of any successful cooperation process (Kolleck and Bormann, 2014). Therefore, as a starting point for the analysis, educational institutions should exchange detailed information about their respective educational realities. In addition to educational policy frameworks, the different curricular requirements must also be analysed, which initially may often appear to have little potential for interconnection within an institution, but also between the phases of teacher education (Rieckmann and Holz, 2017; Hammerness and Klette, 2015; Hellmann, 2019). This makes it all the more important to spell out from the outset what basic visions and hindrances exist for curriculum development, and what paths need to be taken to pursue them successfully.

Further, the individual preconditions and attitudes of the educators at the respective institutions must also be taken into account. As already explained, it may be assumed that the majority of people working at teacher education institutions are not sufficiently familiar with the concept of sustainable development, and opinions on the content and objectives of ESD can vary greatly. In addition, ESD is a normative term (Shephard et al., 2018), which is why the question is often raised, particularly in the natural sciences, as to what extent it is appropriate from an academic perspective to impart values at all.

In addition, initiating and carrying out projects for the structural implementation of ESD involves a great deal of time and, particularly when international cooperation partners are involved, financial expenditure for all persons and institutions involved (Christoforatou, 2015). One thinks, for example, of the numerous debates that must be held when sounding out network partners and designing the content of programmes, taking into account different framework conditions and participating in calls for funding proposals, with communication often taking place in one or more foreign working language(s). Precisely because a large number of teachers and educational administrators have not yet personally experienced a change of perspective with regard to the SDGs, many do not immediately understand the importance of interdisciplinary cooperation, the involvement of partners outside school, or the integration of mobility stays or measures for internationalization at home for the development of job-related skills in the field of ESD. One should therefore be prepared for considerable reservations on the part of teachers and educational administrators. Taking them seriously and addressing them appropriately is an essential condition for the success of structural implementation.

\section{Develop and implement teaching/learning arrangements that promote ESD}

What might future-oriented teaching/learning arrangements in school lessons look like in order for students to develop creative skills? What opportunities are available in 
subject-related lessons, but also as part of interdisciplinary teaching/learning scenarios? How can school partnerships and exchange programmes be used specifically to empower all those involved?

With regard to these issues, teacher-educators are faced with the challenge of offering (student and trainee) teachers various opportunities to train and further develop their own professional competences relevant to ESD (Burow and Gallenkamp, 2017). To this end, it is necessary to develop, test, evaluate, and possibly revise, innovative teaching/learning scenarios. In this context, the framework A Rounder Sense of Purpose provides several possibilities (Vare et al., 2019). Depending on the specific objectives, these teaching/learning scenarios may be subject-related, but also interdisciplinary and/or international. In view of the different curricular requirements and basic organizational conditions, it is advisable to coordinate different focuses within the three phases of teacher education, and to develop appropriate teaching/ learning formats accordingly. For example, interdisciplinary approaches and mobility stays (as part of semesters abroad, school internships, excursions or courses) can be integrated systematically into university-based teacher education (Falkenhagen et al., 2019). For the second and third phases of teacher education, there is much to be said for making subject-related practical teaching issues the starting point for joint work, and enriching them in a multi-perspective manner, for example, as part of longerterm series, of in-service training courses, possibly in the form of blended learning arrangements (Lipowsky and Rzejak, 2019).

The decision to integrate ESD into teacher education requires a systematic expansion of the range of courses on offer (Holst and Brock, 2020). This can be done by teacher educators identifying suitable elements of knowledge and teaching/learning arrangements based on the question of how their respective subjects or subject areas can contribute to the development of competences. For example, this could be achieved by developing integrative teaching formats in which examples of social practice are examined from the perspectives of subject theory, subject teaching and educational theory. In this respect, the Qualitätsoffensive Lehrerbildung programme, which is funded by the Federal Ministry of Education and Research (BMBF), and which is supporting 59 German universities with 500 million euros, offers a wide range of starting points (BMBF, 2017).

\section{Establish a strategic local and global education network}

As the interim results of the Qualitätsoffensive Lehrerbildung reveal, the connection of the different phases of teacher education, as well as the implementation of crossstructures within an institution, are essential factors for any innovation within teacher education (BMBF, 2019). With regard to ESD, another important condition for success is the establishment of a reliable, issues-based education and cooperation network. Throughout Germany, for example, there are UNESCO schools, Fairtrade schools, Start Green@Schools, Weltethos-Schools (Global Ethic schools) and Club of Rome schools, each with a specific profile approach that can be used to address issues of sustainable development (Kohlmann and Overwien, 2017). With a view to participating institutes of tertiary education, existing specialist groups with research links to individual SDGs should be involved. Moreover, it would be advisable to involve civil society actors who can broaden perspectives on thematic fields (Diersen and Paschold, 2020). In order to initiate changes in perspective, content-related networking with foreign universities and schools should also be carried out.

Such ventures should not fail for financial reasons. The German Academic Exchange Service (DAAD) offers funding opportunities, as does Engagement Global, 
Erasmus+ or the Pädagogischer Austauschdienst (PAD), a department of the KMK which works to promote international exchange and cooperation in the school sector. The PAD not only promotes school partnerships and in-service training courses for teachers from Germany, which, as the examples of good practice published on the internet reveal, often include themes of ESD, but also places teachers from overseas in schools in Germany for a period of between two weeks and 12 months. The integration of such incoming teachers offers significant potential, particularly with a view to addressing global issues.

Precisely because ESD is still poorly anchored in educational processes, international networking with educational institutions or countries such as India in which good practice models have already emerged, and which can provide experience-based suggestions for the development of their own programme, is also recommended (Kanaujia and Gorana, 2019). The involvement of universities that offer online courses or blended learning arrangements is also conceivable. For example, the massive open online course (MOOC) The Sustainable Development Goals - A Global, Transdisciplinary Vision for the Future of the Sustainability Science Centre at the University of Copenhagen offers student teachers new opportunities not only to acquire specific knowledge and cognitive skills, but also to network internationally (https://sustainability.ku.dk/studies/mooc/).

\section{Create win-win situations}

The long-term sustainability of networks is heavily dependent on the extent to which the network partners can identify with the goals and contents of cooperation beyond individual projects over the long term, both institutionally and on a personal level. In the case of interdisciplinary and international collaborative efforts, it is therefore essential to design concepts in such a way that strategic partners can also derive individual benefit from joint projects over the long term, in other words, beyond singular, externally funded projects.

For example, win-win situations can be created by linking elements of initial teacher education and in-service training in such a way that the expertise and areas of activity of all those involved can be made available to best advantage for study, teaching, research, schools and study seminars (Bürgener and Barth, 2020). In addition, synergy effects may be achieved if a university, with the involvement of experts from the second and third phases, were to develop and offer a theory-based and targetgroup-specific, accredited in-service training programme for teachers and teacher trainers of potentially all subjects and school types. Such a qualification programme should include not only educational theory, but also subject-related and teaching components, and even offer participants opportunities for expanding their intercultural and foreign language skills in the context of international activities. Designed as a blended learning arrangement, stages of theoretical input and practical testing could be linked with each other. It could even make sense to bring those teachers together with student teachers completing their school internships. Practical trial stages at schools could, in turn, be evaluated and conceptually developed within the framework of university research projects.

\section{Evaluate measures and derive consequences}

As research on the integration of ESD into teacher education is currently still limited (Singer-Brodowsky et al., 2019; Waltner et al., 2018; Holst and Brock, 2020; Holst and von Seggern, 2020), parallel to the implementation of a package of measures, it is 
important to investigate the extent to which the educational realities at the participating institutions are changing at all. For example, it is useful to evaluate the development, testing and optimization of innovative participatory teaching/learning methods, to investigate the synergy potential for involvement of ESD in all pillars of teacher education (subject theory, subject teaching, educational theory and practical school studies), and to analyse which needs-based offers of support and services are suitable for the selective elimination of existing doubts and obstacles within the individual teacher education institutions. In this context, research should also be conducted into: (1) the challenges facing teachers, education administrators and political decision makers who are dedicated to the systematic integration of ESD into teacher education processes (Duveneck et al., 2020); (2) which measures are suitable for implementing appropriate organizational development processes within the participating institutions (Bormann and Nikel, 2017); and (3) clarifying cross-phase governance issues (Hellmann, 2019).

The aforementioned open communication between the cooperation partners is an essential success factor, even with regard to the communication of research results. Only on the basis of a research design that repeatedly questions the effectiveness of the strategic concept constructively and critically, and that provides concrete indications of the need for optimization in the operational area, can successive structures of crossphase teacher education be established.

\section{Be aware: The process will never end}

TESD is an educational and social innovation (Bormann, 2013) within a specific region that is initiated and/or supported (or, otherwise, hindered) by different actors. Within the participating educational institutions, teachers are the key actors in organizational change processes. No matter how hard ESD experts, the heads of educational institutions or even governments try to implement this innovation, as long as teachers and teacher educators are not convinced of the idea, they will always find opportunities to withdraw. For this reason, teachers play an essential role in organizational development processes; their involvement in the development and implementation of measures is essential (Ingrisch, 2000).

Furthermore, in view of upcoming governance processes involved in shifting the ESD transfer at state level, it is important to always combine education policy demands with clarification of resource issues. The application of ESD to education processes is a task that cannot be carried out either as an ancillary activity or as part of thirdparty-funded projects of limited duration. In the public sector, it is therefore necessary - in addition to the qualification of teachers - to press for the establishment of civil service positions for educational managers who are authorized to coordinate and guide strategy development and implementation processes in the complex and sometimes contradictory situation described above. Such permanent positions are immensely important for establishing structures in the individual German states, as they are the only way to ensure that the concerns of TESD are represented on a permanent basis and independently of individuals. However, a legal basis is needed for the establishment of such posts and for providing them with the necessary resources. Not least for this reason, it is imperative that the issue of ESD be anchored in the teacher education legislation of the German states. In this light, TESD therefore means lobbying members of parliament and cabinet ministers, trade unions and other political stakeholders.

Finally, it must be taken into account that if the conceptual objectives and measures are, as suggested above, linked to research questions, they will necessarily change as the endeavour progresses. This is also due to the fact that the participants will continuously expand their ESD-related key competences and expertise in the 
course of their progressive professionalization, and contribute new findings as stimuli for revising or further developing the concept. For this reason, TESD can be seen as a circular endeavour that - in the best of cases - will never end.

\section{Conclusion: So, what's the homework?}

TESD is a change management process that has only just begun in Germany. There are still considerable differences between what is meant by a structural implementation of ESD into formal education processes and what needs arise from this in terms of teacher education, both between the individual German states and individual teacher education institutions. Thus, 'teacher education for sustainable development' is proving to be an ambiguous term, and the fact that the understanding of the normative concept of ESD can be 'negotiated' (Bormann and Nikel, 2017: 801) implies a wide range of options for shaping it. In order to avoid the risk of diluting the issue, it is all the more important to finally liberate the debate from its niche existence and continue to advance it further. The ESD indicators developed within the framework of the National Monitoring for ESD Implementation in Germany help clarify the needs and achievements of ESD implementation in the field of teacher education, and therefore represent an important reference point for the forthcoming discourse (Waltner et al., 2018).

The conceptual approach outlined above suggests that the implementation of ESD in teacher education should be designed as an overall process. For the successful integration of this cross-sectional task, it makes sense to involve as many stakeholders as possible from the outset in the preparation of the various concepts, and the development and implementation of content-related and organizational measures, and to support them with research. In this way, it can be ensured that ESD is not reduced to combining and labelling individual activities, but rather refers to a systems-based approach to sustainable development that has a lasting effect on all levels of teacher education and demonstrably promotes the professionalization of teachers and teacher educators. The efforts involved are enormous: they imply nothing less than a paradigm shift in teacher education. However, this is indispensable if we wish to take Agenda 2030 and Target 4.7 of the SDGs in particular seriously and apply them to Germany.

Looked at in this way, it is high time that we finally do our homework.

\section{Declarations and conflict of interests}

The author declares no conflicts of interest with this work.

\section{Notes on the contributor}

Ellen Christoforatou is Executive Director of the Center for Teacher Education at the University of Kassel, Germany. Her duties include coordinating the contents of training, and the strategic and organizational development of interdisciplinary cooperation projects. Since 2012, Christoforatou has been coordinating a working group in which educational researchers and teaching subject researchers from various faculties jointly develop curricular and university-based concepts for integrating ESD and international dimensions into teacher education. Together they have implemented the study profile InterESD (Internationalization and Education for Sustainable Development), which enables student teachers to obtain relevant knowledge and competences throughout their regular studies. 


\section{References}

Andreotti, V. (2006) 'Soft versus critical global citizenship education'. Policy \& Practice: A development education review, 3, 40-51. Accessed 14 May 2021. www.development educationreview.com/issue/issue-3/soft-versus-critical-global-citizenship-education.

Barth, M. and Rieckmann, M. (2009) 'Experiencing the global dimension of sustainability: Student dialogue in a European-Latin American virtual seminar'. International Journal of Development Education and Global Learning, 1 (3), 23-38.

Beule, A. and Seybold, H. (2015) 'Nachhaltigkeit lehren - Kompetenzaufbau bei Lehrenden und Multiplikatoren'. Pädagogik, 8, 28-32. https://doi.org/10.3262/PAED1508028.

Bhabha, H. (1990) 'The third space: Interview with Homi Bhabha'. In Rutherford, J. (ed.) Identity, Community, Culture, Difference. London: Lawrence \& Wishart, 207-21.

Bormann, I. (2013) 'Bildung für nachhaltige Entwicklung als Praxis sozialer Innovation'. In RückertJohn, J. (ed.) Soziale Innovation und Nachhaltigkeit: Perspektiven sozialen Wandels. Wiesbaden: Springer VS, 269-88.

Bormann, I. and Nikel, J. (2017) 'How education for sustainable development is implemented in Germany: Looking through the lens of educational governance theory'. International Review of Education, 63 (6), 793-809. https://doi.org/10.1007/s11159- 017-9683-9.

Brock, A. (2018) 'Verankerung von Bildung für nachhaltige Entwicklung im Bildungsbereich Schule'. In Brock, A., de Haan, G., Etzkorn, N. and Singer-Brodowski, M. (eds) Wegmarken zur Transformation - Nationales Monitoring von Bildung für nachhaltige Entwicklung in Deutschland. Berlin: Verlag Barbara Budrich, 67-118.

Brock, A. and Grund, J. (2019) Bildung für nachhaltige Entwicklung in Lehr-Lernsettings Quantitative Studie des Nationalen Monitorings. Befragung von Lehrerlnnen [Executive Summary]. Accessed 14 May 2021. www.researchgate.net/publication/328960201_Bildung_ fur_nachhaltige_Entwicklung_in_Lehr-Lernsettings-Quantitative_Studie_des_nationalen_ Monitorings-Befragung_von_Lehrerlnnen_Executive_Summary.

Bürgener, L. and Barth, M. (2020) 'Die Zusammenarbeit von Lehrkräften, Hochschule und außerschulischen Bildungsakteuren - kollaborative Materialentwicklung unter der Perspektive BNE'. ZEP, 43 (2), S. 4-10. https://doi.org/10.31244/zep.2020.02.02.

BMBF (Bundesministerium für Bildung und Forschung/Federal Ministry of Education and Research) (2017) New Approaches to Teacher Training: Incentives from the programme 'Qualitätsoffensive Lehrerbildung'. Accessed 10 January 2021. www.qualitaetsoffensive-lehrerbildung.de/files/ BMBF-Neue_Wege_in_der_Lehrerbildung_kurz_engl_barrierefrei.pdf.

BMBF (Bundesministerium für Bildung und Forschung/Federal Ministry of Education and Research) (2019) Interim Results of the 'Qualitätsoffensive Lehrerbildung': Initial findings from research and practice. Accessed 10 January 2021. www.qualitaetsoffensive-lehrerbildung.de/files/BMBF_ QLB_2019_ENG_barrierefrei.pdf.

Burow, O.A. and Gallenkamp, C. (eds) (2017) Bildung 2030 - Sieben Trends, die Schule revolutionieren. Weinheim: Beltz.

Christoforatou, E. (2011) 'Third Space'. journal für lehrerinnenbildung, 2/2011, 51-4.

Christoforatou, E. (2014) 'Planning and teaching lessons in transnational teams: Outline of an interdisciplinary, transnational course with Swedish and German student teachers'. In lucu, R., Pecek, M. and Schratz, M. (eds) Changing Roles of Teachers in the European Context. Bucharest: Ars docendi, 19-32.

Christoforatou, E. (2015) 'Auf den Inhalt kommt es an. - Perspektiven der Umsetzung eines themenzentrierten Internationalisierungskonzepts'. In Kricke, M. and Kürten, L. (eds) Internationalisierung der Lehrerlnnenbildung. Münster: Waxmann, 110-23.

Christoforatou, E. (2017) 'Universitäre Lehrerbildung für nachhaltige Entwicklung - eine Sisyphosaufgabe?' Der pädagogische Blick, 25 (1), 19-29. https://doi.org/10.3262/PB1701019.

Christoforatou, E. and Glaser, E. (2020) 'Bildungsreisen als politisch-pädagogisches Programm: vom Austausch zur systematischen Integration'. In Reef, B., Henkel, N. and Bade, G. (eds) Politische Bildung: vielfältig - kontrovers - global. Festschrift für Prof. Dr. Bernd Overwien. Frankfurt/M.: Wochenschau, 103-18.

de Haan, G. (2008) 'Gestaltungskompetenz als Kompetenzkonzept für Bildung für nachhaltige Entwicklung'. In Bormann, I. and de Haan, G. (eds) Kompetenzen der Bildung für nachhaltige Entwicklung. Operationalisierung, Messung, Rahmenbedingungen, Befunde. Wiesbaden: Springer VS, 23-44.

Deutsche UNESCO-Kommission (2020) Übersicht über die BNE-Aktivitäten der einzelnen Bundesländer. Accessed 17 May 2021. www.bne-portal.de/de/bundeslaender-1724.html.

Diersen, G. and Paschold, L. (2020) 'Außerschulisches Lernen - ein Beitrag zur Bildung für nachhaltige Entwicklung und Inklusion'. ZEP, 43, 11-19. https://doi.org/10.31244/zep.2020.01.03. 
Duveneck, A., Singer-Brodowski, M. and von Seggern, J. (2020) Die Governance von Bildung für nachhaltige Entwicklung (BNE) auf dem Weg vom Projekt zur Struktur. Accessed 10 January 2021. www.ewi-psy.fu-berlin.de/einrichtungen/weitere/institut-futur/Projekte/Dateien/Duveneck_-A_Singer-Brodowski_-M_-von-Seggern_-J_-_2020_Die_Governance_von_BNE.pdf.

Falkenhagen, C., Grimm, N. and Volkmann, V. (eds) (2019) Internationalisierung des Lehramtsstudiums. Modelle, Konzepte, Erfahrungen. Paderborn: Schöningh.

Glaser, N. (2019) 'Viel guter Wille, wenig Forschritte'. Erziehung und Wissenschaft, 10, 12-13.

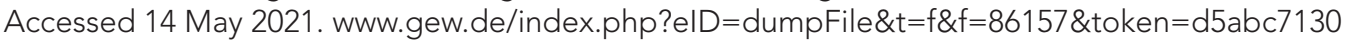

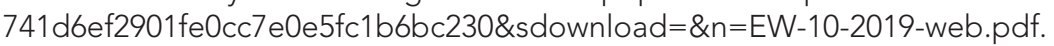

Hammerness, K. and Klette, K. (2015) 'Indicators of quality in teacher education: Looking at features of teacher education from an international perspective'. International Perspectives on Education and Society, 27, 239-77. https://doi.org/10.1108/S1479-367920140000027013.

Hellberg-Rode, G. and Schrüfer, G. (2016) 'Welche spezifischen professionellen Handlungskompetenzen benötigen Lehrkräfte für die Umsetzung von Bildung für Nachhaltige Entwicklung (BNE)?'. Zeitschrift für Didaktik der Biologie - Biologie lehren und lernen, 20 (1), 1-29. https://doi.org/10.4119/zdb-1633.

Hellmann, K. (2019) 'Kohärenz in der Lehrerbildung - Theoretische Konzeptionalisierung'. In Hellmann, K., Kreutz, J., Schwichow, M. and Zaki, K. (eds) Kohärenz in der Lehrerbildung: Theorien, Modelle und empirische Befunde. Wiesbaden: Springer VS, 9-30.

Holst, J. and Brock, A. (2020) Bildung für nachhaltige Entwicklung (BNE) in der Schule: Strukturelle Verankerung in Schulgesetzen, Lehrplänen und der Lehrerbildung. Accessed 10 January 2021. www.ewi-psy.fu-berlin.de/einrichtungen/weitere/institut-futur/Projekte/Dateien/2020_BNE_ Dokumentenanalyse_Schule.pdf.

Holst, J. and von Seggern, J. (2020) Bildung für nachhaltige Entwicklung (BNE) an Hochschulen: Strukturelle Verankerung in Gesetzen, Zielvereinbarungen und Dokumenten der Selbstverwaltung. Accessed 10 January 2021. www.bne-portal.de/files/2020_BNE_ Dokumentenanalyse_Hochschule.pdf.

Ingrisch, E. (2000) 'Mit dem Widerstand - nicht gegen ihn: Vom konstruktiven Umgang mit Widerstand bei Schulentwicklungsprozessen'. Schulmanagement, 31, 13-19.

Kanaujia P.R. and Gorana R.N. (2019) 'Teacher preparation for environmental education and education for sustainable development in India'. In Setty, R., lyengar, R., Witenstein, M., Byker, E.J. and Kidwai, H. (eds) Teaching and Teacher Education: South Asian education policy, research, and practice. London: Palgrave Macmillan, 319-36.

Kohlmann, E.-M. and Overwien, B. (2017) 'BNE und globale Perspektiven in der Lehrerbildung'. ZEP, 40, 27-9. Accessed 14 May 2021. www.waxmann.com/artikelART102313.

KMK (Kultusministerkonferenz) (2014) Geschäftsordnung der Ständigen Konferenz der Kultusminister der Länder in der Bundesrepublik Deutschland gemäß Beschluss vom 19.11.1955 in der Fassung vom 29.08.2014. Accessed 10 January 2021. www.kmk.org/fileadmin/Dateien/pdf/ KMK/GO-GR-Fassung-29-08-2014.pdf.

KMK (Kultusministerkonferenz) (2017) Zur Situation und zu Perspektiven der Bildung für nachhaltige Entwicklung. Bericht der Kultusministerkonferenz vom 17.03.2017. Accessed 14 May 2021. www.kmk.org/fileadmin/Dateien/veroeffentlichungen_beschluesse/2017/2017_03_17-BerichtBNE-2017.pdf.

KMK and BMZ (Kultusministerkonferenz and Bundesministerium für wirtschaftliche Zusammenarbeit und Entwicklung) (eds) (2017) Orientierungsrahmen für den Lernbereich globale Entwicklung im Rahmen einer Bildung für nachhaltige Entwicklung. Accessed 10 January 2021. www.kmk.org/ fileadmin/Dateien/veroeffentlichungen_beschluesse/2015/2015_06_00-OrientierungsrahmenGlobale-Entwicklung.pdf.

Kolleck, N. and Bormann, I. (2014) 'Analyzing trust in innovation networks: Combining quantitative and qualitative techniques of Social Network Analysis'. Zeitschrift für Erziehungswissenschaft, 17,9-27. https://doi.org/10.1007/s11618-014-0551-0.

Lipowsky, F. and Rzejak, D. (2019) 'Konzeptionelle Merkmale wirksamer Fortbildungen für Lehrkräfte'. In Priebe, B., Böttcher, W., Heinemann, U. and Kubina, C. (eds) Steuerung und Qualitätsentwicklung im Fortbildungssystem: Probleme und Befunde - Standardbildung und Lösungsansätze. Hannover: Klett Kallmeyer, 103-51.

Mignolo, W.D. (2012) The Darker Side of Western Modernity: Global futures, decolonial options. Durham, NC: Duke University Press.

National Platform on ESD (National Platform on Education for Sustainable Development) (2017) National Action Plan on Education for Sustainable Development: The German contribution to the UNESCO Global Action Programme. Accessed 10 January 2021. www.bne-portal.de/sites/ default/files/downloads/publikationen/BMBF_NAP_BNE_EN_Screen_2.pdf. 
Pirbhai-Illich, F. and Martin, F. (2019) 'Decolonizing teacher education in immersion contexts: Working with space, place and boundaries'. In Martin, D. and Smolcic, E. (eds) Redefining Teaching Competence through Immersive Programs: Practices for culturally sustaining classrooms, 65-93.

Quezada, R. (ed.) (2012) Internationalization of Teacher Education: Creating globally competent teachers and teacher educators for the 21st Century. New York: Routledge.

Rieckmann, M. and Holz, V. (2017) 'Zum Status Quo der Lehrerbildung und -weiterbildung für nachhaltige Entwicklung in Deutschland'. Der pädagogische Blick, 25 (1), 4-18. https://doi.org/10.3262/PB1701004.

Shephard, K., Rieckmann, M. and Barth, M. (2018) 'Seeking sustainability competence and capability in the ESD and HESD literature: An international philosophical hermeneutic analysis'. Environmental Education Research, 25 (4), 532-47.

Singer-Brodowski, M., Etzkorn, N. and von Seggern, J. (2019) 'One transformation path does not fit all - insights into the diffusion processes of Education for Sustainable Development in different educational areas in Germany'. Sustainability, 11 (1). https://doi.org/10.3390/su11010269.

Staatliches Seminar für Didaktik und Lehrerbildung (WHRS) Freiburg (ed.) (2018) Nachhaltigkeitsbericht des Staatlichen Seminars für Didaktik und Lehrerbildung (WHRS) Freiburg. Accessed 10 January 2021. http://whrs.seminar-freiburg.de/site/pbs-bw-km-root/get/ documents_E665748718/KULTUS.Dachmandant/KULTUS/Seminare/seminar-freiburg-whrs/pdf/ BNE/KM_N-Bericht_SeminarFreiburg_V12.pdf.

Terhart, E. (2004) 'Struktur und Organisation der Lehrerbildung in Deutschland'. In Blömeke, S., Reinhold, P., Tulodziecki, G. and Wildt, J. (eds) Handbuch Lehrerbildung. Bad Heilbrunn: Klinkhardt, 37-59.

UNECE (United Nations Economic Commission for Europe) (2011) Learning for the Future: Competences in Education for Sustainable Development. Accessed 10 January 2021. https://unece.org/DAM/env/esd/ESD_Publications/Competences_Publication.pdf.

UNESCO (United Nations Educational, Scientific and Cultural Organization) (2014) Roadmap for Implementing the Global Action Programme on Education for Sustainable Development. Accessed 10 January 2021. https://unesdoc.unesco.org/ark:/48223/pf0000230514.

Vare, P., Arro, G., de Hamer, A., Del Gobbo, G., de Vries, G., Farioli, F., Kadji-Beltran, C., Kangur, M., Mayer, M., Millican, R., Nijdam, C., Réti, M. and Zachariou, A. (2019) 'Devising a competence-based training program for educators of sustainable development: Lessons learned', Sustainability, 11 (7), 1890. https://doi.org/10.3390/su11071890.

Waltner, E.-M., Rieß, W. and Brock, A. (2018) 'Development of an ESD indicator for teacher training and the national monitoring for ESD implementation in Germany'. Sustainability, 10 (7), 2508. https://doi.org/10.3390/su10072508.

Zeichner, K. (2010) 'Rethinking the connections between campus courses and field experiences in college- and university-based teacher education'. Journal of Teacher Education, 61 (1-2), 89-99. https://doi.org/10.1177/0022487109347671. 